\title{
Praiseworthy Character Instruments Development Culinary Students Through Cooperation Habituation Course Practice Groups In Food Processing
}

\author{
Sugijono, Badraningsih Lastariwati, Sutriyati Purwanti \\ Jurusan Pendidikan Teknik Boga dan Busana \\ Fakultas Teknik, Universitas Negeri Yogyakarta \\ Yogyakarta, Indonesia \\ giyono@uny.ac.id \& sugiyono.ab@gmail.com
}

\begin{abstract}
This study set out from the problems of unavailability of instruments that measure habituation cooperation within the group in the course of food processing practices. This research aims to develop an evaluation tool to measure the cooperation within the group include: (1) ability to solve problems in groups, (2) cooperate in a group activity, and (3) the ability to collaborate in groups. This research use approach research and development $(R \& D)$ with the steps: (1) preliminary studies, (2) model development, (3) model testing, and (4) publication. Conclussion show that: (1) problem solving instrument consists of five indicators, cooperation instruments consist of seven indicators, collaborate instrument consists of 8 indicators; (2) based on the goodness-of-fit test problem solving instruments, instruments of cooperation, collaboration instrument has good validity of the instrument; (3) base on the ICC analysis instruments that problem solving, cooperation instruments, have collaborated instrument reliability, consistency, and stability in good categories.
\end{abstract}

Keywords-: instrument problem solving, collaboration, collaborate

\section{INTRODUCTION}

Character education or character building, teach human to be smart, virtuous, to be able to govern themselves, abstinence, and can manage themselves or self-disciplin, care about other people unselfishly (Ki Hajar Dewantoro, 1977: 544).

Caharacter building can be achieved if people can develop the factors which have been owned. The powers is reasining reasoning power, heart power, and vitality. By sharpening reasoning power, born of scientific capabilities. By sharpening the power of heart, was born faith and morals or characters commendable. By forging the life force, the spirit was born to cope with every challenge facing life.

Universally various characters defined as the value of various characters living together based on pillars of peace, respect, cooperation, freedom, happiness, honesty, humility, affection (love), responsibility, simplicity, tolerance, and unity. Characters are also influenced by heredity and environment. A child's behavior is often not far from the behavior of his father and mother. The social environment also contributes to the formation of one's character. A child who lives in the middle of the harsh social environment, such as in densely populated areas, metropolitan, usually tend to behave in antisocial, loud, emotional, and so on

One of the professional characteristics of Gisslen is the ability to work with people. That means able to work in a team and always work together. Unselfish, appreciate of coworker, favour, substantiate, and were able to control themselves. It is still not much done in practice learning.

Group work method is the format of teaching and learning with an emphasis on the interaction between other members within a group in order to complete learning tasks together actively cooperate and collaborate in groups. Group work method has not been implemented in accordance with the actual nature of the work group.

Based on these descriptions, it can be expressed that the main problem has not been done habituation cooperation within the group to develop praiseworthy character culinary student. An instrument to assessment behavioral habituation cooperation within the group need to be developed. Such an instrument to measure: (1) ability to solve the problems in groups, (2) cooperate in a group activity, (3) the ability to collaborate in groups.

The purpose of this study was to develop an evaluation tool to measure habituation cooperation within the group in the course of food processing practices.

Character building can be achieved if people can develop the forces which have been owned. The powers is reasining power, heart power, and vitality. Through the sharpen reasoning power, was born the scientific capabilities, with power sharpen heart, was born the faith and morals or praiseworthy character, and by forging the power of life was born the spirit of overcoming any challenge life faced.

In general character often associated with unique characteristics, moral strength, or the pattern of a person's behavior. Zamroni (2011: 41) the character is a way of thinking 
and behaving that is typical of each individual to live and work together, both within the family, community, nation, and state. Characters can be considered as the values of human behavior associated with the Almighty God, ourselves, our fellow human beings, the environment, and nationality manifested in thoughts, attitudes, feelings, words, and actions based on religious norms, laws, manners, culture, mores, and aesthetics.

Gisslen (2007: 11) explains that to be a worker in the field of processing and food service required professional standards. Tasks assigned to education the processing and food service is on mastering a set of skills and attitudes. In many ways the attitudes are more important than skills, because a good attitude will not only help to learn skills, but also prepares students to face various difficulties faced in his career later in life.

Praiseworthy character is good ethics, good morals, good manners. Ki Hajar Dewantoro designates that the manners or the character or also called character education, teaches man to be intelligent, virtuous, to be able to govern themselves, abstinence, and can manage themselves or self-discipline, concerned with others unselfishly (Ki Hajar Dewantoro. 1977:544). If the praiseworthy character has become part of his personality he will deliver products and services that can be accounted for morally.

One of the professional characteristics of Gisslen is the ability to work with people. That is able to work in a team and always work together. Unselfish, humble work of fellow workers, jealousy, envy, and were able to control themselves. Working in the field of production can not work alone, all coworkers should be seen as a team. In any case or its potential should be appreciated, should not despise each other, belittle others, feel themselves superior.

Group work method is a teaching-learning format which focuses on the interaction between other members within a group in order to complete learning tasks together. Teaching methods by conditioning the learners in a group or groups of lab work as a whole and given practical assignments to be undertaken in the group. Group work method is the format of teaching and learning with an emphasis on the interaction between other members within a group in order to complete learning tasks together actively cooperate and collaborate in groups.

Application of group work method required to classify learners in a sensible and proportionately. Grouping learners in a group can be based on: (a) facilities available; (b) ndividual differences in interest learning and learning ability; (c) given the type of work; (d) region of residence learners; (e) gender; (f) increase the participation of learners in the group; dan $(\mathrm{g})$ randomly. Furthermore, the division of the group should be heterogeneous, both in terms of learning ability or gender so that the dynamics of learning better and the group was not impressed biased that there is a strong group and there is a weaker party.

Group work method aims to: (1) willingness and ability to foster cooperation among the learners; (2) increasing the involvement of socio-emotional and intellectual the learners in the learning process is be held; (3) increased attention to the process and outcome of the learning process in a balanced.
Reasons for using group work method is to: (1) make learners can cooperate with his colleagues in the unity of duty; (2) develop the strength to seek and find the ingredients to perform these tasks; (3) make learners active.

In this study asked the question: (1) how the construct instruments: solution to problem, cooperation within the group, and collaborate in groups?; (2) how the the construct validity of instruments: solution to problem, cooperation within the group, and collaborate in groups?; (3) how the reliability of the instrument: instruments: solution to problem, cooperation within the group, and collaborate in groups?

\section{METHOD}

This research is a research and development. Instruments problem solving, cooperation within the group, and collaborate in groups, using an approach Research and Development (R\&D) in education (Borg and Gall, 1983: 775-785). Sukmadinata (2008: 184) modifying the approach into three steps: (1) Preliminary studies, (2) Model development, (3) Models testing. This study developed a learning design by step development of the instrument as follows in Fig.1. Step of Instrument Development.

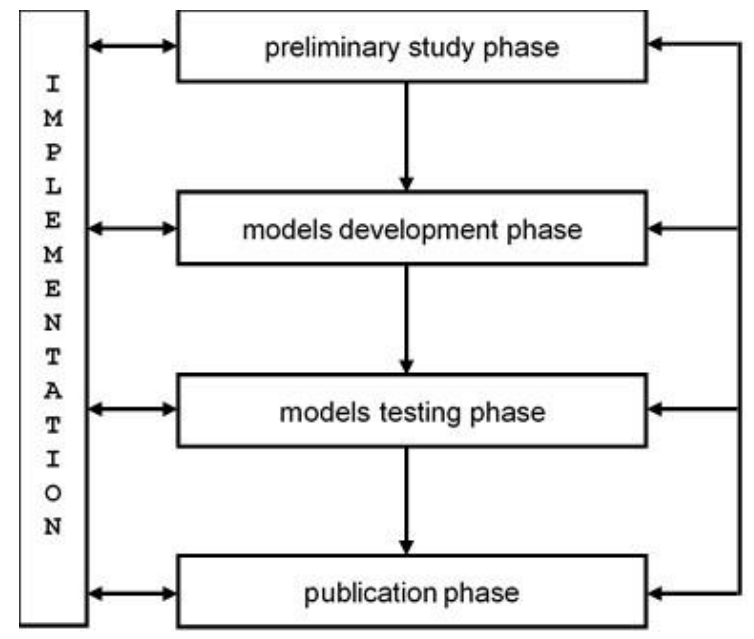

Fig. 1. Step of Instrument Development

The research approach is as follows: (1) Preliminary study, an initial activity that serves to determine the assessment group collaboration on the subject of food processing practices. In this stage the researchers found problems there has been no evaluation tools assessment standardized cooperation within the group. (2) Model development using stages: (a) filter information data generated from preliminary studies to prepare the instrument development steps, (b) develop a draft instrument, (c) construct a instrument prototype, (d) perform validation of the instrument using the Delphi technique. (3) Testing models include: (a) assign trials instruments and organizing, (b) socialization and training to use of instruments, (c) implementation of instruments on limited testing, (d) revise the assessment instrument based on limited testing, (e) testing the effectiveness of the instrument. (4) Publication phase is a 
form of socialization effectiveness of the instrument to the audience much more.

Place of research conducted in the laboratory of food processing Culinary Studies Program, Department of Technical Education of Culinary and Clothing, Faculty of Engineering, Yogyakarta State University. The research was conducted in May 2016 until September 2016. The subject of research and trials models are the students participating in the food processing practices in the second semester of academic year 2015/2016, at Culinary Studies Program, Department of Technical Education of Culinary and Clothing, Faculty of Engineering, Yogyakarta State University.

Research tools are questionnaires and research instruments. The questionnaire used to determine the construct instruments to be used in the development of assessment instruments habituation cooperation within the group. While the instrument is used to measure the validity and reliability of the assessment instrument habituation developed cooperation within the group.

Data analysis included face validity, content validity, construct validity, and reliability estimates. Test the validity of the instrument aims to determine the suitability of the item with the lattice theoretical. Test the face validity of the assessment instrument habituation cooperation within the group carried out by experts by way of expert judgment.

Test the content validity is done by analyzing the data obtained from the evaluation of the experts using the formula Aiken. The prototype instrument rated by experts on conformance between items with grating instruments. Criteria for conformity assessment of the relationship between the items with the lattice using score. The relationship was given a score of 1 if it does not match, a score of 2 if it is less appropriate, a score of 3 if appropriate, and a score of 4 if very appropriate. Scoring results used to determine the validity of the instrument items. The items validity according to Saifuddin Azwar (2012) and Lewis R. Aiken (1985) can be calculated using the formula Aiken.

$$
V=\frac{\sum s}{n(c-1)}
$$

$$
\begin{aligned}
& \text { Annotation: } \\
& \begin{array}{l}
V=\text { validity coefficient } \\
s=r-l o \\
r=\text { the rater's validity rating of the item } \\
l o=\text { lowest validity category } \\
c=\text { higest validity category } \\
n=\text { number of raters }
\end{array}
\end{aligned}
$$

Validity coefficient calculation results compared with Table Aiken, at the 5\% significance level. Items that have a value $\mathrm{V}$ count is greater than or equal to the value of the $\mathrm{V}$-table, then the item is qualify content validity. Conversely, if V-count is smaller than the V-table, then the item is not qualify content validity, meaning that the item should be aborted or repaired.
Construct validity is used to determine the suitability of the measuring instrument measurement results with theoretical constructs of variables studied. The constructs or latent variables can not be measured directly, for the measure to be using indicators or manifest variables that can be measured directly. Data obtained from measurements of these indicators were analyzed quantitatively using Confirmatory Factor Analysis (CFA). Manifest variables grouped into the appropriate factors, through factor analysis, ie extracting the variables. Extraction is done using the method of principal component analysis. So that the results of the factor analysis more convincing needs to be done is a rotation, in this study using Varimax method. Construct validity test carried out on productive performance assessment instrument integrated food field.

Estimated reliability of the constructs used to determine the reliability of the instrument if used at different times or different assessors. Data obtained from measurements indicators were analyzed quantitatively using a program Structural Equation Modeling (SEM). Statistical analysis program that is used is the program Intraclass Correlation Coefficient (ICC). Formula correlation coefficient ICC as follows.

$$
r_{x x}=\frac{\sigma_{s}^{2}}{\sigma_{s}^{2}+\sigma_{o}^{2}+\sigma_{s}^{2}}
$$

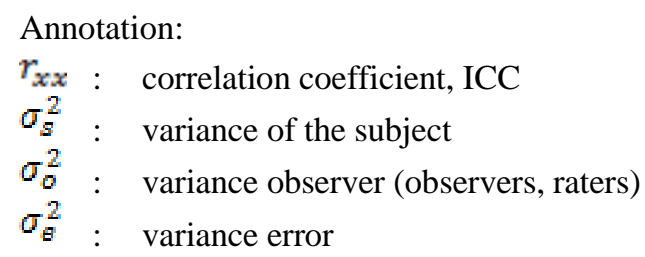

Intraclass correlation coefficients are the ratio between the variance between groups and the total variance. Total variance originated from three sources: the subject, observer, and random error or residual error. The criteria of stability or reliability of the instrument is sufficient stability category (ICC $\geq 0.50$ ) and high stability category (ICC $\geq 0.80$ ).

\section{RESULT AND DISCUSSION}

Preliminary study includes field studies and literature. The survey results of laboratory studies on the field of food processing, through interviews and direct observations obtained by the problem that there has been no evaluation instrument assessment standardized cooperation within the group. Teaching methods by conditioning the learners in a group or groups of lab work as a whole and given practical assignments to be undertaken in the group. Group work method is the format of teaching and learning with an emphasis on the interaction between other members within a group in order to complete learning tasks together actively cooperate and collaborate in groups. Therefore it is necessary for habituation cooperation within the group to develop a praiseworthy character. So the instrument to measure behavioral habituation 
cooperation within the group need to be developed. Such an instrument to measure: (1) ability to solve problems in groups, (2) cooperate in a group activity, (3) the ability to collaborate in groups.

Development of a model using the following steps: (a) filtering data information to prepare the preliminary study instrument development steps, (b) develop a draft instrument, (c) construct a prototype instrument, (d) perform validation of the instrument using the Delphi technique.

Test the validity of the instrument is carried out on three instruments in a group problem-solving skills; instruments work together in group activities; and the instrument's ability to collaborate in groups already meet the criteria for a good instrument or not based apparently (face validity). These instruments in the opinion of experts and practitioners with expert judgment declared qualify face validity in both categories and is ready for use.

Data from the draft instrument rating by experts calculated using the formula Aiken. Criterion of the content validity is the validity coefficient $\mathrm{V}$-count must be equal to or greater than the validity coefficient V-table. Summary results of the calculation of V-Aiken instruments ability to solve problems in the group are presented in Table I. In Table I provides information that all valid indicators.

TABlE I. CAlCulation Results V-Aiken InStRument Problem Solving Ability in Group.

\begin{tabular}{|c|c|c|c|c|c|}
\hline \multicolumn{2}{|c|}{ Item } & \multirow{2}{*}{ Indicator } & \multirow{2}{*}{$\begin{array}{l}\text { V-Aiken } \\
\text { (V-cal.) }\end{array}$} & \multirow{2}{*}{$\begin{array}{c}\left.\text { Criteria }^{*}\right) \\
(5 \%)\end{array}$} & \multirow{2}{*}{$\begin{array}{c}\text { Status } \\
(5 \%)\end{array}$} \\
\hline No. & Var. & & & & \\
\hline 1. & $\mathrm{X} 1$ & Recognizing the problem & 0,89 & 0,78 & Valid \\
\hline 2. & $\mathrm{X} 2$ & Approve the decision & 0,89 & 0,78 & Valid \\
\hline 3. & X3 & Limiting the problems & 0,89 & 0,78 & Valid \\
\hline 4. & $\mathrm{X} 4$ & Scope of the problem & 1,00 & 0,78 & Valid \\
\hline 5. & X5 & Not easily give up. & 0,90 & 0,78 & Valid \\
\hline
\end{tabular}

*) Table Aiken validity criteria based on $\mathrm{c}=4, \mathrm{n}=6$ at $5 \%$ level was 0.78

Therefore instruments in a group problem-solving skills in the opinion of experts qualified content validity and composed by indicators correspond with the theory.

Summary results of the calculation of V-Aiken instrument of cooperation activities within the group are presented in
Table II. In Table II gives the information that all valid indicators. Therefore instruments work together in a group activity in the opinion of experts qualified content validity and composed by indicators correspond with the theory.

TABLE II. CALCULATION RESUlTS V-AiKEN INSTRUMENTS ACTIVITIES COOPERATION IN GROUPS

\begin{tabular}{|c|c|c|c|c|c|}
\hline \multicolumn{2}{|c|}{ Item } & \multirow{2}{*}{ Indicator } & \multirow{2}{*}{$\begin{array}{l}\text { V-Aiken } \\
\text { (V-cal.) }\end{array}$} & \multirow{2}{*}{$\begin{array}{c}\left.\text { Kriteria }^{*}\right) \\
(5 \%)\end{array}$} & \multirow{2}{*}{$\begin{array}{c}\text { Status } \\
(5 \%)\end{array}$} \\
\hline No. & Var. & & & & \\
\hline 1. & X6 & Communication between members & 0,94 & 0,78 & Valid \\
\hline 2. & $\mathrm{X} 7$ & Having a relationship & 0,89 & 0,78 & Valid \\
\hline 3. & $\mathrm{X} 8$ & Comprehension ability & 0,94 & 0,78 & Valid \\
\hline 4. & $\mathrm{X} 9$ & Openness & 0,89 & 0,78 & Valid \\
\hline 5. & $\mathrm{X} 10$ & Involving other opinions & 0,94 & 0,78 & Valid \\
\hline 6. & $\mathrm{X} 11$ & Accept other opinions & 0,89 & 0,78 & Valid \\
\hline 7. & $\mathrm{X} 12$ & Having a relationship & 0,89 & 0,78 & Valid \\
\hline
\end{tabular}

*) Table Aiken validity criteria based on $\mathrm{c}=4, \mathrm{n}=6$ at $5 \%$ level was 0.78

Summary results of the calculation of V-Aiken instrument's ability to collaborate in groups are presented in Table III. In Table III gives the information that all valid indicators.
Therefore the instrument's ability to collaborate in groups according to the experts qualify content validity and composed by indicators correspond with the theory. 
TABLE III. CALCUlation RESUlts V-Aiken InSTRUMENTS COLLABORATE ON GROUP CAPABILITIES.

\begin{tabular}{|c|c|c|c|c|c|}
\hline \multicolumn{2}{|c|}{ Item } & \multirow{2}{*}{ Indicator } & \multirow{2}{*}{$\begin{array}{l}\text { V-Aiken } \\
\text { (V-cal.) }\end{array}$} & \multirow{2}{*}{$\begin{array}{c}\left.\text { Kriteria }^{*}\right) \\
(5 \%)\end{array}$} & \multirow{2}{*}{$\begin{array}{l}\text { Status } \\
(5 \%)\end{array}$} \\
\hline No. & Var. & & & & \\
\hline 1. & $\mathrm{X} 13$ & Communicate opinion & 0,83 & 0,78 & Valid \\
\hline 2. & X14 & Tolerant of other opinions & 0,89 & 0,78 & Valid \\
\hline 3. & $\mathrm{X} 15$ & Using the media & 0,94 & 0,78 & Valid \\
\hline 4. & $\mathrm{X} 16$ & Believing others & 0,83 & 0,78 & Valid \\
\hline 5. & $\mathrm{X} 17$ & Receive feedback & 0,89 & 0,78 & Valid \\
\hline 6. & $\mathrm{X} 18$ & Appreciating the decision & 0,89 & 0,78 & Valid \\
\hline 7. & X19 & Implementing the obligations & 0,94 & 0,78 & Valid \\
\hline 8. & $\mathrm{X} 20$ & Can be trusted & 0,89 & 0,78 & Valid \\
\hline
\end{tabular}

*) Table Aiken validity criteria based on $\mathrm{c}=4, \mathrm{n}=6$ at $5 \%$ level was 0.78

Determination of construct validity begins with an analysis of factors. Factors analysis aimed to classify indicators into the appropriate factor using Maximum Likelihood extraction method with Varimax rotation method. Determination of indicators into a factor based on the value of the largest among the loading factors value in the same item. The construct validity determined by Goodness-of-fit test resulting from the extraction process in the factor analysis. The trials conducted on 30 respondents instruments. The results of the factor analysis of individual instruments are presented as follows.

Instruments problem-solving skills in a group composed of 5 items, grouped into corresponding constructs using factor analysis, the results are as follows.

TABLE IV. KMO AND BARTLETT'S TEST

\begin{tabular}{|l|l|r|}
\hline \multicolumn{2}{|l|}{ Kaiser-Meyer-Olkin Measure of Sampling Adequacy. } &, 522 \\
\hline $\begin{array}{l}\text { Bartlett's Test of } \\
\text { Sphericity }\end{array}$ & Approx. Chi-Square & 29,934 \\
\cline { 2 - 3 } & df & 10 \\
\cline { 2 - 3 } & Sig. &, 001 \\
\hline
\end{tabular}

Table IV. KMO and Bartlett's Test gave information KMOMSA value of 0.522 and the value of Chi-Square of 29.934 with degrees of freedom (df) of 10 and a significance level $($ Sig. $=0.001)$. KMO value $(0.522)>0.50$ means that instruments developed in both categories. Value Chi-Square (29.934) and a significance level of Sig. (0.001) meaning that the correlation matrix is not an identity matrix so that it can be used for analysis of factors.
TABLE V. ROTATED FACTOR MATRIX

\begin{tabular}{|l|r|r|}
\hline & \multicolumn{2}{|c|}{ Factor } \\
\hline & 1 & \multicolumn{1}{|c|}{2} \\
\hline x01 &, 989 &,- 143 \\
\hline x02 &, 673 &, 184 \\
\hline x03 &, 138 &, 990 \\
\hline x04 &, 162 &, 069 \\
\hline x05 &, 556 &, 146 \\
\hline
\end{tabular}

Extraction Method: Maximum Likelihood.

Rotation Method: Varimax with Kaiser Normalization. a Rotation converged in 3 iterations.

The results show that the factor rotated the items are grouped into two factors, namely: factor- 1 consists of items $\mathrm{X} 01, \mathrm{X} 02, \mathrm{X} 04$, and X05; whereas factor- 2 consists only of items X03 only.

The results of the analysis of the construct validity of the instrument in a group problem-solving skills with Goodnessof-fit test using Maximum Likelihood method as follows.

TABLE VI. GOODNESS-OF-FIT TEST

\begin{tabular}{|c|c|c|}
\hline Chi-Square & df & Sig. \\
\hline ,811 & 1 & , 368 \\
\hline
\end{tabular}

Chi-Square value calculation result is equal to 0.811 on the degrees of freedom $(\mathrm{df}=1)$ with significance level Sig. $(\mathrm{p}=$ $0.368)$. Value analysis results: $p(0.368)$ is much larger than $\alpha$ (0.05), meaning that there is no difference between the constructs built from theory to construct generated from the analysis of empirical data. Based on the description can be concluded that grouping items into factors or constructs are valid based on the construct validity. So the instrument the ability to solve problems in the group are valid based on the construct validity with $\chi^{2}=0,811$ and $p=0,368$ in the analysis Goodness-of-fit test. 
Instruments of cooperative activity in the group consists of seven items, grouped into corresponding constructs using factor analysis, the results are as follows.

TABLE VII. KMO AND BARTLETT'S TEST

\begin{tabular}{|c|c|c|}
\hline \multicolumn{2}{|c|}{ Kaiser-Meyer-Olkin Measure of Sampling Adequacy. } & \multirow{2}{*}{$\begin{array}{r}, 528 \\
71,441\end{array}$} \\
\hline \multirow{3}{*}{$\begin{array}{l}\text { Bartlett's Test of } \\
\text { Sphericity }\end{array}$} & Approx. Chi-Square & \\
\hline & df & 21 \\
\hline & Sig. &, 000 \\
\hline
\end{tabular}

Table VII. KMO and Bartlett's Test gave information KMO-MSA value of 0.528 and the value of Chi-Square of 71.441 with degrees of freedom (df) of 21 and a significance level $($ Sig. $=0.000)$. KMO value $(0.528)>0.50$ means that instruments developed in both categories. Value Chi-Square (71.441) and a significance level of Sig. $(0,000)$ meaning that the correlation matrix is not an identity matrix so that it can be used for factor analysis.

TABLE VIII. ROTATED FACTOR MATRIX

\begin{tabular}{|l|r|r|r|}
\hline & \multicolumn{3}{|c|}{ Factor } \\
\hline & 1 & \multicolumn{1}{|c|}{2} & \multicolumn{1}{c|}{3} \\
\hline x06 &, 870 &, 450 &,- 201 \\
\hline x07 &,- 133 &, 957 &, 254 \\
\hline x08 &,- 106 &,- 070 &,- 720 \\
\hline x09 &, 751 &, 066 &, 480 \\
\hline x10 &, 673 &,- 273 &, 059 \\
\hline x11 &, 508 &,- 124 &, 108 \\
\hline x12 &, 041 &, 085 &, 567 \\
\hline
\end{tabular}

Extraction Method: Maximum Likelihood.

Rotation Method: Varimax with Kaiser Normalization.

a Rotation converged in 6 iterations.

Rotated factor results indicate that the items are grouped into three factors: factor- 1 consists of items X06, X09, X10, and X11; whereas factor-2 consists of items X07 only, while the 3-factor consists of items X08, and X12.

Results of analysis of construct validity instrument of cooperative activity in the group with Goodness-of-fit test using Maximum Likelihood method as follows.

TABLE IX. GOODNESS-OF-FIT TEST

\begin{tabular}{|c|c|c|}
\hline Chi-Square & df & Sig. \\
\hline 10,490 & 3 & ,085 \\
\hline
\end{tabular}

Chi-Square value calculation result is equal to 10.490 on the degrees of freedom $(\mathrm{df}=3)$ with a significance level Sig. (p $=0.085)$. Value analysis results: $p(0.085)$ is greater than $\alpha$ (0.05), meaning that there is no difference between the constructs built from theory to construct generated from the analysis of empirical data. Based on the description can be concluded that grouping items into factors or constructs are valid based on the construct validity. So instruments work together in group activities is valid according construct validity with $\chi^{2}=10,490$ and $p=0,085$ in the analysis Goodness-of-fit test.

The instrument's ability to collaborate in groups consisting of 8 items, grouped into appropriate constructs using factor analysis, the results are as follows.

TABLE X. KMO AND BARTLETT'S TEST

\begin{tabular}{|l|l|r|}
\hline \multicolumn{2}{|l|}{ Kaiser-Meyer-Olkin Measure of Sampling Adequacy. } \\
\multicolumn{2}{|l|}{} \\
\hline $\begin{array}{l}\text { Bartlett's Test of } \\
\text { Sphericity }\end{array}$ & Approx. Chi-Square \\
\cline { 2 - 3 } & df & 50,860 \\
\cline { 2 - 3 } & Sig. & 28 \\
\hline
\end{tabular}

Table X. KMO and Bartlett's Test gave information KMOMSA value of 0.570 and the value of Chi-Square of 50.860 with degrees of freedom (df) of 28 and a significance level $($ Sig. $=0.005)$. KMO value $(0.570)>0.50$ means that instruments developed in both categories. Value Chi-Square (50.860) and a significance level of Sig. (0.005) meaning that the correlation matrix is not an identity matrix so that it can be used for factor analysis.

TABLE XI. ROTATED FACTOR MATRIX

\begin{tabular}{|l|r|r|r|}
\hline & \multicolumn{3}{|c|}{ Factor } \\
\hline & 1 & 2 & 3 \\
\hline x13 &,- 100 &, 625 &,- 276 \\
\hline x14 &, 358 &, 885 &, 296 \\
\hline x16 &, 080 &, 007 &, 492 \\
\hline x17 &, 323 &, 023 &, 437 \\
\hline x18 &, 458 &, 127 &, 155 \\
\hline x19 &, 491 &, 067 &, 487 \\
\hline x20 &, 238 &,- 015 &,- 101 \\
\hline
\end{tabular}

Extraction Method: Maximum Likelihood.

Rotation Method: Varimax with Kaiser Normalization. a Rotation converged in 5 iterations.

Rotated factor results indicate that the items are grouped into three factors: factor- 1 consists of items $\times 17$, x18, and $\times 19$; whereas factor- 2 consists of items $\mathrm{X} 13$, and $\mathrm{X} 14$, while the 3 factor consists of items X15, X16 and X20.

The results of the analysis of the construct validity of instruments in a group with the ability to collaborate Goodness-of-fit test using Maximum Likelihood method as follows. 
TABLE XII. GOODNESS-OF-FIT TEST

\begin{tabular}{|c|c|c|}
\hline Chi-Square & df & Sig. \\
\hline 2.923 & 7 & 892 \\
\hline
\end{tabular}

Chi-Square value calculation result is equal to 2,923 on the degrees of freedom $(\mathrm{df}=7)$ with a significance level Sig. $(\mathrm{p}=$ $0.892)$. Value analysis results: $p(0.892)$ is much larger than $\alpha$ (0.05), meaning that there is no difference between the constructs built from theory to construct generated from the analysis of empirical data. Based on the description can be concluded that grouping items into factors or constructs are valid based on the construct validity. So the instrument's ability to collaborate in groups based on the valid construct validity with $\chi^{2}=2.923$ and $p=0.892$ in the analysis Goodness-of-fit test.

Evidence of reliability using intraclass correlation coefficients (ICC) with the type of consistency test definition.
ICC analysis used to determine the stability of the instrument, based on the test instrument by rater. The results of the analysis of individual instruments are presented as follows.

Instruments problem-solving skills in a group composed of 5 items tested on 30 respondents. The results of analysis and calculation are presented as follows.

TABLE XIII. RELIABILITY STATISTICS

\begin{tabular}{|r|r|}
\hline $\begin{array}{c}\text { Cronbach's } \\
\text { Alpha }\end{array}$ & N of Items \\
\hline, 787 & 30 \\
\hline
\end{tabular}

The results of the analysis of reliability of the statistics above show that the instruments ability to solve problems in the group have reliabiliti Crombach Alpha coefficient of 0.787 means that the instrument had a reliability in both categories.

TABLE XIV. INTRACLASS CORRELATION COEFFICIENT

\begin{tabular}{|c|c|c|c|c|c|c|c|}
\hline & \multirow{2}{*}{$\begin{array}{l}\text { Intraclass } \\
\text { Correlation }^{a}\end{array}$} & \multicolumn{2}{|c|}{$95 \%$ Confidence Interval } & \multicolumn{4}{|c|}{ F Test with True Value 0} \\
\hline & & Lower Bound & Upper Bound & Value & $\mathrm{df1}$ & $\mathrm{df} 2$ & Sig \\
\hline Single Measures &, $710^{\mathrm{b}}$ &, 020 &, 559 & 4,689 & 4,0 & 116 &, 002 \\
\hline Average Measures &, $787^{\circ}$ & ,382 & 974 & 4,689 & 4,0 & 116 &, 002 \\
\hline
\end{tabular}

Two-way mixed effects model where people effects are random and measures effects are fixed.

a Type $\mathrm{C}$ intraclass correlation coefficients using a consistency definition-the between-measure variance is excluded from the denominator variance.

b The estimator is the same, whether the interaction effect is present or not.

c This estimate is computed assuming the interaction effect is absent, because it is not estimable otherwise.

The results of this analysis tell us about that instrument of problem-solving skills in a group that is tested against 30 respondents produce a single measurement ICC coefficient of 0.710 and a coefficient ICC of 0.787 memelibihi average measurement criteria ICC coefficient of at least 0.70 is required, meaning that the instrument in a problem-solving skills group is reliable and has the consistency and stability in the adequate category.

Instruments problem-solving skills in a group consisting of seven items tested on 30 respondents. The results of analysis and calculation are presented as follows.
TABLE XV. RELIABILITY STATISTICS

\begin{tabular}{|r|r|}
\hline $\begin{array}{c}\text { Cronbach's } \\
\text { Alpha }\end{array}$ & N of Items \\
\hline, 845 & 30 \\
\hline
\end{tabular}

The results of the analysis of reliability of the statistics above show that the instruments ability to solve problems in the group have reliabiliti Crombach Alpha coefficient of 0.845 means that the instrument had a reliability in both categories.

TABLE XVI. INTRACLASS CORRELATION COEFFICIENT

\begin{tabular}{|c|c|c|c|c|c|c|c|}
\hline & \multirow{2}{*}{$\begin{array}{l}\text { Intraclass } \\
\text { Correlation }^{\circledR}\end{array}$} & \multicolumn{2}{|c|}{$95 \%$ Confidence Interval } & \multicolumn{4}{|c|}{ F Test with True Value 0} \\
\hline & & Lower Bound & Upper Bound & Value & df1 & df2 & Sig \\
\hline Single Measures &, $757^{\mathrm{b}}$ & ,005 & ,299 & 2,820 & 6,0 & 174 &, 012 \\
\hline Average Measures & $745^{\circ}$ & 120 & 927 & 2,820 & 6,0 & 174 &, 012 \\
\hline
\end{tabular}

Two-way mixed effects model where people effects are random and measures effects are fixed.

a Type $C$ intraclass correlation coefficients using a consistency definition-the between-measure variance is excluded from the denominator variance.

b The estimator is the same, whether the interaction effect is present or not.

c This estimate is computed assuming the interaction effect is absent, because it is not estimable otherwise. 
The results of this analysis tell us about that instrument of problem-solving skills in a group that is tested against 30 respondents produce a single measurement ICC coefficient of 0.757 and a coefficient ICC of 0.745 memelibihi average measurement criteria ICC coefficient of at least 0.70 are provided herein, means the instrument in the problem-solving skills group has the consistency and stability in the adequate category.

The instrument's ability to collaborate in groups consisting of 8 items tested on 30 respondents. The results of analysis and calculation are presented as follows.
TABLE XVII. RELIABILITY STATISTICS

\begin{tabular}{|r|r|}
\hline $\begin{array}{c}\text { Cronbach's } \\
\text { Alpha }\end{array}$ & N of Items \\
\hline, 846 & 30 \\
\hline
\end{tabular}

Hasil analsis reliability statistics tersebut di atas menunjukkan bahwa instrumen kemampuan berkolaborasi dalam kelompok memiliki koefisien reliabiliti Crombach Alpha sebesar 0,846 artinya instrumen memiliki reliabilitas dalam kategori baik.

The results of the analysis of reliability of the statistics above show that the instrument's ability to collaborate in the group had reliabiliti Crombach Alpha coefficient of 0.846 means that the instrument had a reliability in both categories.

TABLE XVIII. INTRACLASS CORRELATION COEFFICIENT

\begin{tabular}{|c|c|c|c|c|c|c|c|}
\hline & \multirow{2}{*}{$\begin{array}{l}\text { Intraclass } \\
\text { Correlation }^{\mathrm{a}}\end{array}$} & \multicolumn{2}{|c|}{$95 \%$ Confidence Interval } & \multicolumn{4}{|c|}{ F Test with True Value 0} \\
\hline & & Lower Bound & Upper Bound & Value & $\mathrm{df1}$ & $\mathrm{df} 2$ & Sig \\
\hline Single Measures &, $757^{\mathrm{b}}$ & ,007 &, 265 & 2,827 & 7,0 & 203 &, 008 \\
\hline Average Measures & $846^{\circ}$ & , 169 &, 915 & 2,827 & 7,0 & 203 &, 008 \\
\hline
\end{tabular}

Two-way mixed effects model where people effects are random and measures effects are fixed.

a Type $C$ intraclass correlation coefficients using a consistency definition-the between-measure variance is excluded from the denominator variance.

$\mathrm{b}$ The estimator is the same, whether the interaction effect is present or not.

c This estimate is computed assuming the interaction effect is absent, because it is not estimable otherwise.

The results of the above analysis provides information that the instrument's ability to collaborate in a group that is tested against 30 respondents produce a single measurement ICC coefficient of 0.757 and a coefficient ICC of 0.745 memelibihi average measurement criteria ICC coefficient of at least 0.70 are provided herein, means that the instrument has the ability to collaborate in groups consistency and stability in the adequate category.

\section{CONCLUSIONS}

The construct of problem-solving instruments are classified into two factors, construct instruments of cooperation within the group are classified into three factors, and constructs instruments to collaborate in groups grouped into three factors.

Based Goodness-of-fit test instrument problem solving, cooperation instruments in the group, and collaborate in a group of instruments have good validity of the instrument.

Based on ICC analysis, problem-solving instruments, instruments of cooperation in groups and collaborate instruments in the group had a reliability, consistency and stability in both categories.

\section{REFERENCES}

[1] Aiken, Lewis R. (1985). Three coefficients for analyizing the reliability and validity of ratings. Educational and Psychological Measurement. 1985, 45. SAGE Social Science Collections.

[2] Borg, W.R. \& Gall, M.D. (1983). Educational Research An Introduction (4th ed.). New York: Longman Inc.

[3] Dewantoro,H.K.(1977). Bagian pertama: pendidikan. Yogyakarta: Majelis Luhur Taman Siswa.

[4] Gisslen, Wayne. (2007). Profesional cooking. New York: Jhon Wiley \& Son.

[5] Sukmadinata, Nana Syaodih (2008). Metode penelitian pendidikan. Bandung: PT. Remaja Rosdakarya

[6] Zamroni. (2011). Dinamika Peningkatan Mutu, Yogyakarta: Gavin Kalam Utama. 